Stuart, S.A.J. (2013) Privileging exploratory hands: prehension, apprehension, comprehension. In: Radman, Z. (ed.) The Hand, An Organ of the Mind: What the Manual Tells the Mental. MIT Press, Cambridge, Mass., UK. ISBN 9780262018845

Copyright (C) 2013 Massachusetts Institute of Technology

A copy can be downloaded for personal non-commercial research or study, without prior permission or charge

The content must not be changed in any way or reproduced in any format or medium without the formal permission of the copyright holder(s)

When referring to this work, full bibliographic details must be given

http://eprints.gla.ac.uk/60040/

Deposited on: 13 May 2013

Enlighten - Research publications by members of the University of Glasgow http://eprints.gla.ac.uk 


\title{
Privileging Exploratory Hands: prehension, apprehension, comprehension
}

\author{
Susan A. J. Stuart \\ University of Glasgow
}

November 2011

\begin{abstract}
Through our hands we construct our world and through our construction of our world we construct ourselves. We reach with our hands and touch with our hands, and with this reaching and touching we come to understand how things feel and are. It is not an utterable knowledge, yet it is knowing the world in a dynamically-engaged affective, effective way. Through affective feedback our reaching and touching becomes a prehensive grasping which leads, through the enkinaesthetic givenness of the agent with its world, to a situated and embodied knowing, and the rudiments of apprehension. With each fresh comprehension a new enkinaesthetic enquiry is engendered; with each enquiry we have afresh the anticipatory dynamics of reaching, touching and feeling, with the hand-to-object of world-investigation, the hand-to-body of auto-investigation and investigating the Other.
\end{abstract}

\section{Introduction}

It is reputed that Kant once said "The hand is the window to the mind.", though a direct quotation that possesses a neat and easy reference is unlikely to be forthcoming. Yet it is possible to follow some of Kant's earlier reasoning ${ }^{1}$ to demonstrate how this thought can well be ascribed to him. What's more, we can show how essential it is for his later writing where, although he avoids any obvious form of ontological commitment to the nature of the human mind and any direct commitment to the physicality of the hands and body, he nonetheless must do so, not merely as a transcendental condition, but because they perform an essential corporeal and affective role in orientating the subject in space and establishing that subject's egocentric point of view. Our hands are the richly-sensitive instruments with which we begin the sensory enquiry of lived experience, and it is through their feeling-engagement that we construct our world. This claim will be supported by appeal to the affective kinaesthetic and enkinaesthetic engagement with which we are necessarily bound in a relation of felt 'withness' with other agents, organisms, and things. As a consequence of constructing our experiential world we discover ourselves as both transcendental condition - there being a necessary a priori subject of experience, and as an antecedent physical entity, with our sensuous embodiment making prehension, apprehension, by which I mean knowing that we know ${ }^{2}$, and ultimately, a broader comprehension possible.

\footnotetext{
${ }^{1}$ The 'earlier' period referred to here is Kant's 'pre-critical' period, and is associated with the period 1755-1770. It's rather a shame to use the term 'pre-critical' as Shell's marvellous book, The Embodiment of Reason Kant on Spirit, Generation, and Community [1996], attests. Kant's 'critical' period ranges from 1781 to 1796 in which, perhaps most significantly, the Prolegomena and the three Critiques were published.

${ }^{2}$ The action of grasping with the intellect, including forming an idea or conception.
} 
In this discussion I will be using the term 'enkinaesthesia' to mean the reciprocally affective neuro-muscular dynamical flows and muscle tensions that are felt and enfolded between co-participating agents. We move, touch and change one another in myriad different ways with touch having a "phenomenological primacy over the other senses" [Ratcliffe, this volume] . To touch is to awaken to awareness, whether it be direct or indirect touch. Direct touch includes the physical touch of a caress, a pat on the back, a hug, or the rebuff of the shrugged pulling away from contact or the strike of a hand. Indirect touch can be achieved through a look where one becomes the object of someone else's attention and experience ${ }^{3}$, for example, in an unspoken admonishment of a look or a wagging finger, a papal blessing which can shrive us of our sins, a friend's wave from a departing train, the touch of eyes that meet across a room, or in the way words and language can alter the way we feel. And, so, it is clear that although there is no distinct organ of touch, our hands and our skin incorporate the other senses and these inform the proprioceptive, kinaesthetic and, because no touch is ever unidirectional, enkinaesthetic senses with their relative feedback. This is especially evident in the intertwining or chiasm of clasped hands, where the touching hand is itself touched, or when I touch my body in the the hand-to-body of auto-investigation, for then I experience both the touching and the being touched. In that instant I am both subject and object.

This can happen only if my hand, while it is felt from within, is also accessible from without, itself tangible, for my other hand, for example, if it takes its place among the things it touches, is in a sense one of them, opens finally upon a tangible being of which it is also a part. Through this crisscrossing within it of the touching and the tangible, its own movements incorporate themselves into the universe they interrogate ... We must habituate ourselves to thinking that every visible is cut out in the tangible, every tactile being in some manner promised to visibility, and that there is encroachment, infringement, not only between the touched and the touching but also between the tangible and the visible ... There is double and crossed situating of the visible in the tangible and of the tangible in the visible ... [Merleau-Ponty 1968, pp.133-4]

In sensing our world in the hand-to-object of world-investigation or hand-to-body of investigating the Other, our hands make contact in a way that our eyes and ears do not: "in touch we directly appeal to the tactile properties of our own bodies in investigating the self-same tactile properties of other bodies" [O'Shaughnessy, 1989, p.38]. Yet, like the other senses, touch is inextricable from a dynamic moving, sensing and acting living body.

I will develop my argument by using Kant's 1768 essay Concerning the ultimate ground of the differentiation of directions in space in conjunction with Woelert's recent article on "Kant's hands" [Woelert 2007] to draw out why a failure in functional vertical symmetry establishes our physical spatiality and provides us with a situated perspective on a world of other agents, organisms and things. ${ }^{4}$ In addition I will re-present Woelert's claim that Kant's arguments, in this early period, anticipate claims for the constitutive force of the body, yet these are claims which are more usually associated with the phenomenology of the early twentieth century. This emphasis on the body is important because an agent's action constitutes an affectively-laden interrogation of its world, that is, a non-propositional somatosensory questioning of how our world is for us now and, how we anticipate it will continue to be, and this is facilitated by our kinaesthetic and enkinaesthetic engagement. What we discover in this fundamental action is not, at first, an utterable knowing - it is not associated with speech or formal conceptualisation; it is pre-conceptual. Reaching and touching constitutes

\footnotetext{
${ }^{3}$ For an interesting elaboration of how we can be affected by the look of another read Chapter 1 of Part 3 of Being and Nothingness by Sartre.

${ }^{4}$ The term 'functional vertical symmetry' is used deliberately to emphasis the necessity of movement and action in speaking about alignment and orientation, for enantiomorphism alone cannot explain our egocentric orientation. Our hands might very well not have been enantiomorphic, it is, after all, only a contingent feature of our bodily structure, yet we would still have and be able to speak about a right and a left side, and right and left can only be demonstrated and comprehended in the functioning of our hands, or arms, legs, shoulders, and so on.
} 
a prehensive grasping 5 and which forms the essential background to a situated and embodied knowing, and this provides the rudiments of apprehension. With each fresh knowing, or embodied comprehension, a new enkinaesthetic enquiry is engendered. With each enquiry we have afresh the anticipatory dynamics of reaching, touching and feeling, with the hand-to-object of world-investigation, the hand-to-body of autoinvestigation, and the hand-in-hand of investigating the other. In the second half of the paper I will turn to the body and, specifically to the hands, arguing that all the senses but, with greatest vivacity, the hands and touch open new horizons of sensuous opportunity, proximity, and closeness to others: agents, organisms, and things.

\section{Enantiomorphic Hands and their Constitutive Role in our Experience}

By means of a geometrical proof Kant demonstrates that our hands play a crucial role in proving the existence of an absolute space that exists around us and through which we move. Though his proof is geometrical in spirit its consequence is phenomenological, and most interestingly phenomenological because, of all the possibilities within our functional vertical symmetry, ears, nostrils, eyes, arms, legs, and so on, he choses the hands, hands which feel and grasp and bring us explicitly into a pre-noetic epistemic phenomenology.

If we permit ourselves a momentary consideration of this issue we can begin to make sense of some of the reasons why Kant may have chosen the hands to exemplify the notion of irreconcilable spatial opposition and our physical being in the world. For one thing our hands, but not our nostrils, eyes and ears or tongue, are laid out before us and can become the focus of these other senses. For another, in their dexterous, and sometimes not so dexterous, fingering and handling engagement our hands express our, predominantly, pre-propositional questions about how our world continues to be - searching, fumbling, reaching, touching, grasping, lifting, holding, caressing, stroking, feeling, the size, shape, texture, tension, density, softness, and pliability of that with which we are in immediate encounter. Through this swiftly habituated affective tactual perception our hands become the means for a great deal of our skilful engagement with our world. Yet, there is a problem. As Wilson [1998] states in his Prologue: "Our lives are so full of commonplace experience in which the hands are so skillfully and silently involved that we rarely consider how dependent upon them we actually are." [p.3]. They are our sensuous root in and route into our world, yet as a result of their success they become, in many ways, invisible. ${ }^{6}$ From as early as eleven weeks the foetus stretches, reaches and touches the local world within which it is situated.

Human foetuses tentatively touch the placenta, umbilicus and the uterine wall with their hands at 11 weeks. They make jaw movements and swallow amniotic fluid, expressing pleasure or disapproval at tastes injected into it by sucking and smiling or grimacing with disgust. Complex movements of trunk, arms and legs position the body, and may react to the mothers body movements and the contractions of the muscles of her uterus (Lecanuet, et al., 1995; Piontelli, 2002; Trevarthen, et al., 2006). (Trevarthen and Reddy, 2007)

When asked 'where are you' we often gesture vaguely to our chest, the site of our felt breathing and heartbeat, or to somewhere behind our eyes, even though we only sometimes consciously direct their gaze. We rarely open our hands out in front of our body and say "This is where I am.". We can look down at our chest, but our eyes, our ears and nostrils are invisible to us unless we perceive them in a mirror or touch them with our hands. Our arms and legs may raise us up and, even, propel us forward into the space around us, yet it is our hands which disclose our world to us, sensually eliminating the apparent barrier between us and our

\footnotetext{
${ }^{5}$ The term 'grasping' is deliberately ambiguous, taken to mean both taking hold with our hands and understanding.

${ }^{6}$ One might consider in this context the phrase that has become the byword for familiarity: "I know X like the back of my hand", but when asked to describe the back of our hand we find ourselves at a complete loss.
} 
world. ${ }^{7}$ They express explicitly our intertwining with our world where we oscillate between experiencing as perceiving object and being the subject of perception: "When I press my two hands together, it is not a matter of two sensations felt together as one perceives two objects placed side by side, but of an ambiguous set-up in which both hands can alternate the rôles of 'touching' and being 'touched'." [Merleau-Ponty 1962, p.93] These points, I will maintain, were, in some form, apparent to Kant.

So, let's return to Kant's proof. His intention is to prove that "Absolute space, independently of the existence of all matter and as itself the ultimate foundation of the possibility of the compound character of matter, has a reality of its own." (Kant 2002, p.366; emphasis as in original), and the basis for his claim is that it is only with reference to the sides of our body, and more specifically our hands, that we can even begin to make sense of geographical orientation [Gegend / Gegenden, according to Walford [2001]] and the notion we have of distinct places [Lagen]. His formal argument states that:

If two figures drawn on a plane surface are equal and similar, then they will coincide with each other. But the situation is often entirely different when one is dealing with corporeal extension [bodies] ... They can be exactly equal and similar, and yet still be so different in themselves that the limits of the one cannot also be the limits of the other ... [T] he most common and clearest example is furnished by the limbs of the human body, which are symmetrically arranged relative to the vertical plane of the body. The right hand is similar and equal to the left hand. And if one looks at one of them on its own, examining the proportion and the position of its parts to each other, and scrutinising the magnitude of the whole, then a complete description of the one must apply in all respects to the other, as well.

I shall call a body which is exactly equal and similar to another, but which cannot be enclosed in the same limits as that other, its incongruent counterpart. [Kant 2002, pp.369-70]

His point is clear, the intrinsic descriptions of the relations of the parts of a hand are equivalent whether we refer to the left or the right hand, but the hands themselves are mirror images of one another. They are enantiomophs which evade "integration into a homogenous and purely self-referential form of space" [Woelert 2007, p.139] within which they could dissolve and disappear from the physical world. It is the fact that they don't and can't that is crucially important. Our hands are equal and similar in the relation of their parts, but their distinct orientations demonstrate that they are topologically non-identical. As Hanna says:

[I]ncongruent counterparts are perceivable mirror-reflected spatial duplicates that share all the same monadic properties, have exactly the same shape and size, and correspond point-for-point, but are in different places and cannot be made to coincide by rigid translation within the same global orientable space (an orientable space is a space with intrinsic directions). Even more briefly put, incongruent counterparts are enantiomorphs. Enantiomorphs are qualitatively identical but topologically non-identical. [Hanna 2008, p.53-4]

\footnotetext{
7،"The boundaries which seem to separate us from our worlds open us up to those worlds and reveal to us our inseparability from them. Those boundaries which can appear, at first, rigid and fixed are often malleable and semi-permeable. We need think only of the skin with its surfaces within surfaces [Hoffmeyer 2008, pp17-38], the biological membranes of stratum corneum, epidermis, dermis and subcutaneous tissue, and our sense receptors and nerves; then there are the hairs that respond to temperature, which can stand erect if we are suddenly fearful, and which can be brushed by a sleeve or touched gently by a breeze; and then there are the non-biological membranes of clothes with their textures and degrees of translucency, and our personal and social boundaries which vary in relation to our moods and emotions, our confidence, our company, our feeling of well-being and health, and so on. Our natural assumption is to see the boundary of the body as the limit of our experiential world, but it is precisely its semi-permeable nature its breach which provides us with the possibility of experience in the first place. The skin, overrun with an abundance of receptors - sixty kilometres of nerve fibres, fifteen kilometres of veins, with millions of sense receptors for pain, temperature, pressure and touch [Hoffmeyer 2008, p.18] - opens us up to the world and discloses it through our inescapable engagement with it, and then, of course, the skin is supplemented by the plenisentience of visual, proprioceptive, kinaesthetic, auditory, gustatory, and olfactory senses which open us up in their own way, are affected by change or motion within our world and which, with internal feedback, can bring about affective change within themselves." [Stuart 2010, p.306]
} 
It is their topological non-identity, emphasised by their inherent directionality, which forces them apart into different places within a space that is ontologically, but - though it seems unnecessary to say it - not epistemically or phenomenologically, independent of us. Kant continues:

[I]magine that the first created thing was a human hand. That [hand] would have to be either a right hand or a left hand. The action of the creative cause in producing the one would have of necessity to be different from the action of the creative cause producing the counterpart.

Suppose that one were to adopt the concept entertained by many modern philosophers, especially German philosophers, according to which space simply consists in the external relation of the parts of matter which exist alongside each other. ... [Since] there is no difference in the relation of the parts of the hand to each other, and that is so whether it be a right hand or a left hand; it would therefore follow that the hand would be completely indeterminate in respect of such a property. In other words, the hand would fit equally well on either side of the human body; but that is impossible. (Kant 2002, p.371)

This impossibility, because there exist failures in our functional vertical symmetry, makes it possible to establish both our physical spatiality as corporeal bodies and our individually situated perspectives on our world. Additionally, and crucially, it makes possible our ability to align or orient ourselves in space, firstly in relation to the directionality of our hands in their touch and in their grasp, and then in their motile relation to other objects, agents, people, and our own body. ${ }^{8}$ As Hanna says, Kant's argument thus demonstrates "that the actual space of perceivable material bodies is intrinsically directional (i.e., orientable) and egocentricallycentered". [Hanna 2008, p.55] So, to take a concrete example, we understand the orientation of a map and the direction shown by a compass needle in relation to how we, with our hands, are holding the instruments and, thus, in orientation to our corporeally extended body. This is not to deny other salient cues (or clues), like the orientation of the written script, the positioning of the cardinal points, and so on, but recognising them and grasping them as meaningful comes much later in a mediated conceptualisation of what is, at first, sensuously and immediately to hand. This two phase understanding is not lost on Kant for he says "Even our judgements relating to the cardinal points of the compass are, in so far as they are determined in relation to the sides of our body, subject to the concept that we have of directions in general." [Kant 2002, p.367]. Fundamentally we possess a "referential anchoring in the oriented structure of the human body" [Woelert 2007, p.142] and this is understood with reference to "universal space as a unity" [Kant 2002, p.365]..$^{9}$ Thus Woelert continues:

[I]t is only via our body that we can distinguish between these Gegenden ${ }^{10}$ in space, and it is only in doing so that we (as situated in space through our body) are able to actually grasp space as a whole in the first place. ... space is of direct practical use only when we can relate it to the primordial spatiality of our body ... . [Woelert 2007, p.142]

Key to this passage are the notions of 'via our body' and 'grasp'; the former because of its emphasis on the processual physicality of movement, sensing, orientation and location, and the latter because, although it

\footnotetext{
${ }^{8}$ More will be said about this in the next section; for now our emphasis is on orientation and directionality, and establishing a corporeally-based perspective.

${ }^{9}$ The greater context is given as: "The direction [Gegend], however, in which this order of parts is directed (wohin diese Ordnung der Theile gerichtet ist), refers to the space outside the thing. To be specific: it refers not to places [Lagen] in the space - for that would be the same thing as regarding the position of the parts of the thing in question in an external relation (in einem äusseren Verhältnis) - but rather to universal space as a unity, (auf den allgemeinen Raum als eine Einheit) of which every extension must be regarded as a part." [Kant 2002, pp.365-6]. Walford [2001] presents a compelling case for Kant's argument making sense, only if 'Gegend' is translated as 'direction' or Richtungen, as Kirchmann [1873] does, and not as 'region' as other commentators have done.[Walford's own recommendation for where this 'error' can be seen most clearly is in Van Cleve \& Frederick's collection of essays (1991)].

${ }^{10}$ Woelert translates Gegenden as 'regions'. Whether we use 'regions' or 'orientations' in this particular quotation makes no material difference to the import of this present paper.
} 
is used as a metaphor for understanding, it appeals to our original pre-linguistic manual prehension of our world and how our sensory engagement comes to have meaning for us. ${ }^{11}$ It is within this intricate sensory, manual, somatic, affective interplay - the kind we associate primarily with the reaching, touching, groping and grasping of young children and mistakenly think secondary in the language-using organism - that we embody our pragmatic concernful relations. [Merleau-Ponty 1962; Heidegger 1968; Gendlin 1992] Which is merely to say, as others have said before, that it is from the cycle of perception and action that meaning for the organism emerges. [See, for example, Lakoff \& Johnson (1980), von Uexküll (1982), Johnson (1987), Hodges (2007), Hodges \& Baron (2007), and Steffensen \& Hodges (2010).] "[E]very action, therefore, that consists of perception and operation imprints its meaning on the meaningless object and thereby makes it into a subject-related meaning-carrier in the respective Umwelt (subjective universe)" [von Uexküll 1982 / 1940, p.31]. In this respect the moving, feeling body has a constitutive role, for every action is affectively replete with concernful, values-realising exploration within the immanent habitus of the agent.

\section{Hands as the Orienting Structures of Self-referential Anchoring}

Referential anchoring begins with the body but is phenomenally most striking through the orientating structures disclosed in the unfolding of our hands in space before us and around us. As our hands open out with their palms facing up we feel, as it were from the inside, and see, as it were from the outside, ourselves, oriented against background phenomena. In the dark my groping with my right hand does not feel like groping with my left; they have a distinct phenomenal orientation which forms in us, passively and involuntarily, and constructs a distinct phenomenal-somatic alignment with our world. When I grasp the apple in front of me with my right hand, my thumb is on the left; when I grasp with my left hand the position of my thumb is reversed, the same is true if one hand is grasping the other; they each possess a unique orientation or

\footnotetext{
${ }^{11}$ Kant is notable amongst his fellows for claiming that "There can be no doubt that all our knowledge begins with experience." [Kant 1929, B1 p.41] without dissolving into scepticism as Hume [1978] and Berkeley [1710] did before him. Berkeley's famous dictum esse est percipi (aut percipere) - to be is to be perceived (or to perceive), follows from a marvellously clear claim he makes in Principles:

It is indeed an opinion strangely prevailing amongst men, that houses, mountains, rivers, and in a word all sensible objects, have an existence, natural or real, distinct from their being perceived by the understanding. But, with how great an assurance and acquiescence soever this principle may be entertained in the world, yet whoever shall find in his heart to call it in question may, if I mistake not, perceive it to involve a manifest contradiction. For, what are the forementioned objects but the things we perceive by sense? and what do we perceive besides our own ideas or sensations? and is it not plainly repugnant that any one of these, or any combination of them, should exist unperceived? [Berkeley 1710, p.31]

It is the imagination, as 'metaphysical glue', in Hume's writing which gives us our natural tendency to believe in the existence of real and persistent mind-independent objects. Otherwise, "what Hume discovered is that rational analysis of our ideas shows that, except for mathematics, our ideas are inadequate representations of the reality they purport to be about" [Livingston 1984, p.194].

The central intention of the first Critique, from which the quotation is taken, is to determine the necessary pre-conditions for the very possibility of experience and, as mentioned earlier, he makes no explicit ontological commitment to the nature of such transcendental conditions. (This is by no means a criticism of Kant; two hundred-plus years later our position on the categorial structures for experience and the integration of the senses is still some distance from resolution.) However, the claim for experience as fundamental is not made lightly and it becomes clear to the reader that the transcendental conditions include, not only space and time as a priori forms of intuition, the a priori categories of the understanding, and the transcendental unity of apperception, but also the existence of a spatiallyextended physical world which we come to know through our affective corporeal engagement, and which orientates us and establishes our point of view.

But Kant's triumph in this respect is relatively short-lived; all too soon again we cognitivise and disembody the human mind. Thought is given a pre-eminence over feeling and bodies become the otherwise invisible vehicles of content. Under this conception our referential anchor shifts from the body to the relative latecomer, the disembodied pronoun, 'I', which, through its use as some sort of communicative prosthesis, claims to refer to the - entirely illusory - 'self' which is neither animated physical agent, nor historically, socially and morally-formed person. [Stuart 2006] Cognitivism and computationalism are two of the greatest culprits in this area for they present the mind as symbolic, representational, and reducible to a set of physical states and processes that are fully-explicable through scientific experiment and analysis. These theories emphasise the 'mental', in this case the propositional and disembodied, at the expense of the physical, and continue to forge a spurious dichotomy, whilst mostly claiming not to be dualist. It is most perplexing.
} 
directionality. So it is, that each hand, in its affective-anticipatory, enkinaesthetic engagement has a distinctive feel which brings with it, implicitly and involuntarily, the direction of my body. If we think again of the map, there are lots of cues for its orientation in relation to us, but primarily these are phenomenal and distinctly left and right; I could not have my hands crossed, or have the map behind me or to one side, without the phenomenal experience being entirely distinct and, what's more, distinguishable at a somatosensory kinaesthetic, and thus, enkinaesthetic level.

This deeply felt engagement takes place amidst the multifarious modes of pre-noetic self-givenness, ${ }^{12}$ but in the movement of our hands this givenness has a distinctive flavour; it is one in which we experience simultaneously the interiority of 'auto-affection' [Henry 1963] alongside the putative exteriority of the visual sensation. This is not a characteristic shared by any other sense because of the phenomenological primacy of touch. In the plenisentient activity of the senses and, thus, in our experience more broadly, our hands are inextricably entangled. Their entanglement possesses a "presentational immediacy", whether it is of one hand touching or grasping the other or the "perceptive mode in which there is clear, distinct consciousness of the 'extensive' relations of the world." [Whitehead 1978, p.61], and it brings about the collapse of the artificial interior-exterior sensory division and is suggestive of an altogether more radical interiority. [Henry 1963] The synthesis of such a radical interiority is characterised by its immanence, its direct non-duality, through which the senses, including the enkinaesthetic sense and the proprioceptive and vestibular systems, constitute the agent's 'sense-full' givenness. In this context 'sense-full' implies replete, that is, full of the senses (plenisentient), but it also implies coherent in the sense that "the reactions of an organism are not edifices constructed from elementary movements, but gestures gifted with an internal unity" [Merleau-Ponty 1963, quoted Baldwin 2004, p.51], and full of meaning in its pragmatic values-realising, concernful enaction. ${ }^{13}$

Concernful enaction emphasises agential, sensory and "corporeal anticipation" [Sennett 2008], described enkinaesthetically, because of its inherent affective community and reciprocity, as the organism's anticipatory affective dynamics [Stuart 2010 \& in progress]; and such dynamics make possible the formation of kinaesthetic memories, melodies and habits. "[W]ith the development of motor skills the individual impulses are synthesized and combined into integral kinaesthetic structures or kinetic melodies" [Luria 1973, p.176] which possess an "internal articulation and as a kinetic melody gifted with a meaning . . . [they carry within themselves] ... an immanent intelligibility" [Merleau-Ponty 1963, quoted Baldwin 2004, p.51]. It is, as Merleau-Ponty says, that "habit has its abode neither in thought nor in the objective body, but in the body as mediator of a world" [Merleau-Ponty 1962, p.168], and there is no more palpable sensory mediator than our hands and our skin. It is through our hands that we first develop kinaesthetic habits, like grasping a rattle or taking hold of our foot, which bring with them expectations and anticipations of how our world will continue to be.

In a pre-noetic sense we speak of the lived and knowing body, as opposed to the "Cartesian corpse" [Leder $1992]^{14}$ of our practices as skillful, and of the way in which habitual actions can be characterised by the readiness-to-hand of absorbed coping, possessing a

...practical non-thetic intentionality [which] has nothing in common with a cogitatio (or a noesis) consciously orientated towards a cogitatum (a noema), ... [but is] rooted in a posture, a way

\footnotetext{
${ }^{12}$ The givenness and ownership of an agent's experience results from the agent's neuromuscular dynamics - without movement there can be no affect, without affective movement, there is no agential givenness. Affective movement is always with, and within, the agent's world, so, givenness is at core necessarily enkinaesthetic.

13 'Sense-full' is a term coined by O'Connor [2007] when she speaks of the bodily intentionality manifested in the performance of a skilled action; she says: "Thus, in virtue of bodily intentionality, the particular techniques become "sense-full." In addition it is also very satisfyingly redolent of 'hand-full' and full hands.

${ }^{14}$ Feuerbach is a super nineteenth century example of such writing: "Only the sensuous is clear and certain. Hence, "the secret of immediate knowledge is sensuousness" [Feuerbach 1843/1972, GW IX: 321; PPF 55]. "Whereas the old philosophy started by saying, "I am an abstract and merely a thinking being to whose essence the body does not belong", the new philosophy, on the other hand, begins by saying, "I am a real, sensuous being and indeed, in its totality is my ego, my essence (Wesen) itself." [ibid., GW IX: 320; PPF 54] "When sensuousness begins all doubts and quarrels cease. The secret of immediate knowledge is sensuousness". [[ibid., §38]
} 
of bearing the body (a hexis), a durable way of being of the durable modified body which is engendered and perpetuated, while constantly changing ... in a twofold relationship, structured and structuring, to the environment. [Bourdieu 2000, pp.143-144].

By "twofold" Bourdieu is not endorsing a dichotomy, rather he is emphasising the processual dynamic structural coupling that exists for organisms and their worlds. As a recursively dynamic coupling it must be enkinaesthetic, having the capacity to move and be moved, to shape and be shaped, and comprising no well-defined boundaries between agents, actions, and objects.

If one may consider the environment of a system as a structurally plastic system, the system and its environment must then be located in the intricate history of their structural, enkinaesthetic transformations, where each one selects the trajectory of the other one. [Varela 1989 quoted in Bitbol \& Luisi 2004, p.102; where 'enkinaesthetic' is my addition.]

Cotterill [2001] comments on anticipation when he speaks of the difference between probing-by-movement associated with simple organisms like Eschericia coli and Euglena gracilis and probing-by-proxy associated with organisms that have both a central nervous system and muscle spindles. In both cases movement is involved but in the latter it can be as a covert modification of existing reflexes, making possible the anticipation of action possibilities, something which is crucial because "understanding is not concerned with grasping a fact but with apprehending a possibility of being" [Ricoeur 1981, p. 56]. It is only in this way that we can prepare for fulfilled anticipations, and for contingency and surprise.

[W] e are not conscious of something unless were [sic] are covertly setting up the muscular movements associated with its perception, and such movements will have had to be learned from prior experience. The mechanism thus mediates influence on a currently proceeding (or currently planned) muscular act. That influence stems from motivation-triggered anticipation of the act's outcome ... [Cotterill 2001, p.7]

And, in the preceding paragraph in his text there is even greater emphasis on the anticipatory mechanism in relation to the prehension, and possible, apprehension of the intentional trajectory of the Other's action and movement.

The clue, I strongly feel, lies in the word anticipation. If we are not actively attending to something in our environment, our nervous system will not be able to predict the likely continuation of that something's present trend ...". [ibid.]

Now let's bring this discussion back to Kant and the crucial constitutive role in experience played by the hands and the body. We have already seen that it is through our hands that we begin the richly sensitive felt enquiry that composes our lived experience, and synchronous with this enquiry is the composition or construction of a spatially-extended experiential world. With their non-reductive nature Kant has shown that our, qualitatively identical but topographically non-identical, hands play an essential corporeal role in establishing an external world and orientating us in space, but he is also aware of the affective nature of this experience, that the phenomenal subject is not some abstract, yet logically necessary, transcendental condition, but a sensuous physical entity.

In an intriguing paper, written in 1766, Kant claims that "I am just as immediately in the tips of my fingers, as in my head." [Kant 1766, p.49] for, he argues, "where I sense, there I am". [ibid.] 
No experience teaches me to believe some parts of my sensation to be removed from myself, to shut up my Ego into a microscopically small place in my brain from whence it may move the levers of my body-machine, and cause me to be thereby affected. ...my soul is as a whole in my whole body, and wholly in each part. [ibid.; emphasis as original]

In these claims Kant brings together the notions of a transcendental egocentric point of view with an embodied phenomenologically-rich subject of experience. In other words, it is a geometrically-borne, physicallyextended, enkinaesthetically-embedded subject that feels its way, searching and fumbling, reaching and touching, grasping, lifting, holding, caressing, and stroking, towards a pre-noetic prehensive comprehension. In this unceasing process of investigation and manipulation the agent experiences - from moment to moment - felt epiphanies, when the immanence of our engagement is disclosed, ${ }^{15}$ and reveal, an everchanging, flowing an updating range of, new action possibilities. Through this perpetual exploratory sensuous entanglement we can know how to go on without knowing reflexively and propositionally that it is we who know how to go on. This is not to suggest an absence of egocentricity, for it is very clear from Kant's writing that a first person perspective, as a nomologically necessary transcendental subject, is still present. What we need to understand from his writing is that the egocentric point of view exists but is known only because of the agent's primitive and pervasive sensuous phenomenology.

I hold, [that] this ability of a conscious living organism like us to have a single point of view is grounded in egocentrically centered embodiment, and a primitive bodily awareness that includes proprioception (the sense of ones own body parts and limbs), kinaesthesia (the sense of bodily movement), the sense of orientation and balance, bodily pleasures and pains, tickles and itches, the feeling of pressure, the feeling of temperature, the feelings of vitality or lethargy, and so-on. [Hanna 2008, p.59]

It is with, and only with, my body that I am able to exist in relation to things in the world, and it is with my hands that I am able to directly manipulate and bring about change in my world, and yet at the same time it is through my bodily sensing and touching engagement that I can experience, most readily, the immanence of the Other in my enkinaesthetically attuned absorbed coping. Whitehead presents this forcefully when he says that "the 'withness' of the body is an ever-present, though elusive element in pure perceptions of presentational immediacy" [Whitehead 1978, p.474f]. The affectively-rich, or plenisentient, givenness of the body is a necessary accompaniment to my experience, for the "primordial locality of the lived human body becomes something that I am, ... passively and habitually instituting the field of our subjectivity" [Woelert 2007, p.147]. Though Kant doesn't refer to it in these terms, it is still the field of subjectivity, the 'withness' of the body, and the inherent directionality of felt engagement, to which he refers in this passage:

Considering the things which exist outside ourselves: it is only in so far as they stand in relation to ourselves that we have any cognition of them by means of the senses at all. It is not therefore surprising that the ultimate ground on the basis of which we form our concept of directions in space, derives from the relation of these intersecting planes to our bodies. [Kant 1992, p.366]

There is an enkinaesthetic emphasis on the field of subjectivity which is necessarily composed of the sensuous activity of affective 'being-with' other agents and objects in the world. "[T]he human body invokes a correction according to which space ... is conceived not as a passive representation but as an active process essentially structured by the subject's directed and sensuous activity themselves." [Woelert 2007, p.146] Thus we can understand what it means when we say that it is through our hands that we construct our world, that is, our field of subjectivity, and through our construction of our field of subjectivity that we construct ourselves.

\footnotetext{
${ }^{15}$ One might also think of this in terms of Heidegger's concepts of 'de-distancing', 'disclosedness' and 'attunement', but that must await another opportunity. [Heidegger 1968]
} 


\section{Conclusion}

In conclusion let's consider the place of our hands in the world; they don't emanate from nowhere, they belong in orientation and alignment with the rest of the body, but they are extended from the core of the body and reach out to touch and manipulate what they perceive. They move in relation to one another, frequently acting in conjunction, but sometimes not, and in this way they cannot be thought passive. Their activity in our world is located in the intricate history of our structural, enkinaesthetically-felt coupling. They encounter perturbations, feel difference, and engender change. It is swiftly apparent just how different they are from the eyes or other senses, though it is the eyes which are usually taken to be our predominant sense. Whilst it is true that we can touch someone with a look or affect someone with a gaze, and it is true that all our sensory activity contributes to the formation of our subjective field, it is with our hands that we most directly grasp and enact our sensory engagement. Through the eyes alone we have managed to imagine ourselves a disembodied ego with a narrow to invisible field of subjectivity. But this cannot be done if we accept our hands and our skin as our fundamental or primordial means for affective, effective engagement with our world. Where the hands are recognised as the body's animate instruments of direct touch and change, the field of subjectivity cannot consist only of the pure ego, or of transcendental structures alone. Historically we seem to "have ignored the more inarticulate background of feeling in which those distinct elements are imbedded" [Cory 1933, p.31], and if now we "go back to the facts" and accept Kant's arguments for the constitution of an absolute and phenomenal space, we will be compelled to accept both that "the transcendental functioning of space implies the transcendental functioning of the human body" [Woelert 2007, p.145] and that our field of subjectivity is wide, sensuously-rich and constant only in its capacity for change.

If the hand is the window to the mind, it is only because the hand can grasp its world, prehending and comprehending it in ways that make the organism more effective in its engagement, and to do this it needs a moving, feeling body that, in its affective enkinaesthetic activity, can anticipate and enact the hand-to-object of world-investigation, the hand-to-body of auto-investigation and investigating the Other. It is only then that the hand can construct its world and the mind can be revealed.

\section{Bibliography}

Baldwin, T. (2004) Maurice Merleau-Ponty: basic writings, Routledge, London

Berkeley, G. (1710) A Treatise Concerning the Principles of Human Knowledge, Reprint edition, 1913, Chicago, IL: Open Court Publishing Company.

Bourdieu, P. (2000) Pascalian Meditations, translated by R. Nice, Polity Press, Cambridge

Cichetti, D. and Cohen, D. J. (2006) Developmental Psychopathology, Volume 2, *John Wiley \& Sons, Inc.

Cory, D. (1933) “Dr Whitehead on Perception”, The Journal of Philosophy, 30 (7), pp.29-43

Cotterill, R.M.J. (2001) “Evolution, Cognition and Consciousness”, Journal of Consciousness Studies, 8 (2), pp.3-17

Deleuze, G. \& Guattari, F. (1980) A Thousand Plateaus, trans. Brian Massumi. London and New York: Continuum, 2004. Vol. 2 of Capitalism and Schizophrenia, 2 vols. 1972-1980, trans. of Mille Plateaux. Paris: Les Editions de Minuit

Deleuze, G. (2006) "Immanence: A Life”, in Two Regimes of Madness, New York: Semiotexte

Depraz, N. (2010) "Phenomenology of surprise", in T. Nenon \& Ph. Blosser eds., Advancing Phenomenology, Essays in Honor of Lester Embree, Springer, Contributions to Phenomenology 62, pp.223-35. 
Feuerbach, L. (1843/1972) Principles of the Philosophy of the Future, (Part III) trans. Hanfi, New York: Doubleday

Hanna, R. (2008) “Kantian Non-Conceptualism', Philosophical Studies, 137 (1), pp.41- 64

Heidegger, M. (1968) Being and Time, Trans. J. Macquarrie and E. Robinson, New York: Harper and Row Henry, M. (1963/1973) L'Essence de la manifestation /The Essence of Manifestation, The Hague: Nijhoff

Hodges, B. H. (2007) "Values Define Fields: The Intentional Dynamics of Driving, Carrying, Leading, Negotiating, and Conversing”, Ecological Psychology, 19 (2), pp.153-78

Hodges, B. H. \& Baron, R. M. (2007) "Values as constraints on affordances: Perceiving and acting properly", Journal for the Theory of Social Behaviour, 22 (3), pp.263-94

Hoffmeyer, J. (2008) Biosemiotics, An examinations into the Signs of Life and the Life of Signs, trans. J. Hoffmeyer \& D. Favareau, University of Scranton Press, Scranton and London

Hume, D. (1978) A Treatise of Human Nature, edited, with an analytical index by L.A. Selby-Bigge, (first published 1739, translation 1888), Oxford : Clarendon Press

Husserl, E. (1970) Logical Investigations, trans. J. N. Findlay, vol. 1, New York: Humanities Press

Johnson, M. (1987) The body in the mind: the bodily basis of meaning, imagination, and reason, Chicago, Ill: The University of Chicago Press

Kant, I. (1766) "Dreams of a Spirit-Seer Illustrated by Dreams of Metaphysics", translated by E. F. Goerwitz \& edited, with an Introduction and notes, by Frank Sewall, (1900) London: Swan Sonnenschein \& Co., Lim. New York: The Macmillan Co., accessed at http://ia600204 .us.archive.org/0/items/ dreamsofspiritse00kant/dreamsofspiritse00kant.pdf

Kant, I. (1902ff) “Träume eines Geistersehers, erläutert durch Träume der Metaphysik” In Kants Werke, Akademie Ausgabe, Vol. II (Ak II, pp. 315373), Berlin: Georg Reimer/deGruyter (Original work published 1766).

Kant, I. (1992) "Dreams of a spirit-seer elucidated by dreams of metaphysics", D. Walford trans. in D. Walford \& R. Meerbote, eds, The Cambridge Edition of the Works of Immanuel Kant. Theoretical Philosophy, 1755-1770, Cambridge: Cambridge University Press, pp.301-359

Kant, I. (1929) The Critique of Pure Reason, translated by Norman Kemp Smith. Macmillan Press, (A edition $1781+\mathrm{B}$ edition 1787).

Kant, I. (2002), "Concerning the ultimate ground of the differentiation of directions in space", in D. Walford $\&$ R. Meerbote, eds, The Cambridge Edition of the Works of Immanuel Kant. Theoretical Philosophy, 17551770, Cambridge: Cambridge University Press, pp. 365-72

Kirchmann, J. H. von (1873) “Erläuterungen zu Kants kleinern Schriften über Logik und Metaphysik(Philosophische Bibliothek 58), Berlin

Lakoff, G. \& Johnson, M. (1980) Metaphors we live by, Chicago, Ill: University of Chicago Press

Lecanuet, J.-P., W. P. Fifer, N. A. Krasnegor \& W. P. Smotherman (eds.) (1995) Fetal Development: A Psychobiological Perspective, Hillsdale, NJ: Erlbaum

Leder, D (1992) The Body in medical thought and practice, Kluwer Academic Publisher, Dordrecht, The Netherlands

Livingston, D. (1984) “Review of The Sceptical Realism of David Hume”, Hume Studies, X (2), pp.193-200

Luria, A. R. (1973) The Working Brain: an introduction to neuropsychology, trans. Basil Haigh, London: Allen Lane 
Merleau-Ponty, M. (1962) Phenomenology of perception, trans. by Colin Smith, London: Routledge \& Kegan Paul; New York: The Humanities Press

Merleau-Ponty, M (1963) The Structure of Behavior trans. by Alden Fisher, Boston: Beacon Press; original (1942) La Structure du comportement, Paris: Presses Universitaires de France

Merleau-Ponty, M. (1968) The Visible and the Invisible, Evanston: North Western Press

O’Connor, E. (2007) "Embodied knowledge in glassblowing: the experience of meaning and the struggle towards proficiency”, The Sociological Review, 55, Issue Supplement s1, pp.126-41

Piontelli, A. (2002) Twins: From Fetus to Child, London: Routledge

Ratcliffe, M.J. (2008) Feelings of Being: Phenomenology, Psychiatry and the Sense of Reality, Oxford University Press

Ricoeur, P. (1981) Hermeneutics and the Human Sciences, Cambridge: Cambridge University Press

Sennett, R. (2008) The Craftsman, New Haven: Yale University Press

Sheets-Johnstone, M. (2003) 'Kinesthetic Memory’, Theoria et Historia Scientiarum, 7, pp.69-92

Steffensen, S. V. \& Hodges, B. H. (2010) "The ecology of values-realizing in dialogical and social systems", Paper given at the symposium Expression, Engagement, Embodiment: The Ecology of Situation Transcendence, University of Glasgow, February 2010

Stein, E. (1964) On the Problem of Empathy, trans. Waltraut Stein (1989) The Hague: Martinus Nijhoff

Stuart, S.A.J. (2006) "Extended Body, Extended Mind: The Self as Prosthesis", in Screen Consciousness: Mind, Cinema and World, Amsterdam, New York: Rodopi

Stuart, S.A.J. (2007) "Machine Consciousness: Cognitive and Kinaesthetic Imagination”, Journal of Consciousness Studies, Imprint Academic, 14 (7) pp.141-53

Stuart, S.A.J. (2010) "Enkinaesthesia, Biosemiotics and the Ethiosphere”, in Signifying Bodies: Biosemiosis, Interaction and Health, pp.305-30, ISBN 978-972-697-191-7

Stuart, S.A.J. (2011) "Enkinaesthesia: the fundamental challenge for machine consciousness", International Journal of Machine Consciousness, 3 (1), pp.145-62

Stuart, S.A.J. (forthcoming) "Enkinaesthesia: the essential sensuous background for co-agency", In: Radman, Z. (ed.) The Background: Knowing Without Thinking, Palgrave Macmillan

Stuart, S.A.J. (in progress) "Enkinaesthesia and Reids natural kind of magic"

Trevarthen, C., K. J. Aitken, M. Vandekerckhove, J. Delafieldt-Butt \& E. Nagy (2006) "Collaborative Regulations of Vitality in Early Childhood: Stress in Intimate Relationships and Post natal Psychopathology" in Cichetti \& Cohen (2006)

Trevarthen, C. and V. Reddy (2007) "Consciousness in infants" in M. Velman and S. Schneider (Eds.) $A$ Companion to Consciousness (Oxford: Blackwells), pp.41-57

van Cleve, J. \& Frederick, R. E. (editors) (1991) The Philosophy of Right and Left: Incongruent Counterparts and the Nature of Space, Dordrecht; London : Kluwer Academic Publishers

Varela, F. (1989) "Reflections on the circulation of concepts between a biology of cognition and systemic family therapy", Family Process, 28, pp.1524

von Uexküll, J. (1982 / 1940) “The theory of meaning”, Semiotica 42 (1), pp.25-87

Walford D. [2001] “Towards an Interpretation of Kants 1768 Gegenden im Raume Essay”, Kant-Studien, 92 (4), pp.407-439 
Whitehead, A. N. (1978) Process and Reality, edited by Griffin \& Sherburne, The Free Press, New York

Wilson, F. R. (1998) The Hand: How its use shapes the brain, language, and human culture, Vintage Books, Random House Inc., New York

Woelert, P. (2007) "Kant's hands, spatial orientation, and the Copernican turn", Continental Philosophy Review, 40, pp.139-50 